\title{
Praksisseminar fremmer profesjonsidentitet for sykepleierstudenter
}

Sykepleierstudenter har lav profesjonsidentitet sammenliknet med andre studentgrupper .

Gjennom praksisseminarer vil lærere ved NTNU styrke studentenes identitet som sykepleiere.

\section{Forfattere}

\section{Heidi Killingberg}

Universitetslektor

Institutt for samfunnsmedisin og sykepleie, Fakultet for medisin og helse, NTNU

\section{Marit Gjemdal}

Universitetslektor

Institutt for samfunnsmedisin og sykepleie, Fakultet for medisin og helse, NTNU

\section{Ola Bratås}

Førsteamanuensis

Institutt for samfunnsmedisin og sykepleie, Fakultet for medisin og helse, NTNU

\section{Nøkkelord}

\author{
Evaluering Samarbeid Sykepleierolle Sykepleierstudent Sykepleierutdanning
}

Sykepleien 2018 106(65158)(e-65158)

DOI: https://doi.org/10.4220/Sykepleiens.2018.65158

\section{HOVEDBUDSKAP}

Praksisseminar kan være en egnet arena for å diskutere og klargjøre sykepleierens kompetanse, funksjon, oppgaver og ansvar, og kan dermed bidra til å styrke sykepleieridentiteten blant bachelorstudenter i sykepleie.

Etter forskrift til rammeplan for sykepleierutdanning (1) skal praksisstudier utgjøre 90 studiepoeng, hvorav 75 (50 uker) skal benyttes direkte mot pasienter og pårørende. Rammeplanen (2) sier videre at alle praksisstudier skal være veiledet, og at veiledningen skal foregå i et samarbeid mellom lærer fra utdanningen og praksisveileder i klinikken.

Målsettingen er at «sykepleierutdanningen skal utdanne selvstendige og ansvarsbevisste endrings- og pasientorienterte yrkesutøvere som viser evne og vilje til en bevisst og reflektert holdning ved utøvelse av sykepleie» (2, s. 5).

\section{«Hensikten med praksisseminaret var å samle sykepleierstudenter og lærere til dialog om sykepleierens funksjon i praksis.»}


Et seminar er et godt utgangspunkt for diskusjon og dialog (3). Det innebærer også økt studentaktivitet i forhold til tradisjonell forelesning (4). Hensikten med praksisseminaret var derfor å samle sykepleierstudenter og lærere til diskusjon og dialog om sykepleierens funksjon i praksis gjennom en beskrivelse av kompetanse, ferdigheter og ansvar. I denne artikkelen presenteres og diskuteres studentenes evaluering av praksisseminaret.

\section{Profesjonell identitet}

Ifølge Kunnskapsdepartementet (2) skal sykepleierutdanningen blant annet utdanne yrkesutøvere med kritisk refleksjon i utøvelsen av faget. En viktig forutsetning for det er identitet til egen profesjon. Det innebærer en form for profesjonell identitet, der en gjennom samhandling med andre i samme profesjon oppdager hva som er særegent for egen profesjon og praksis, og hva som skiller dem fra andre profesjoner (5).

Imidlertid viser det seg at sykepleierstudenter har lav profesjonsidentitet sammenliknet med andre grupper, det være seg fysioterapistudenter eller medisinstudenter (므). Det kan skyldes at sykepleierutdanningen er en generalistutdanning, «der formålet ... er å utdanne yrkesutøvere som er kvalifisert for sykepleiefaglig arbeid i alle ledd av helsetjenesten, i og utenfor institusjoner» (2, s. 4).

\section{Rollemodeller}

Når det gjelder utvikling av sykepleieridentitet hos studenter, fant Walker og medarbeidere (6) fem viktige faktorer: positive rollemodeller, tilhørighet, støtte fra medstudenter, kritisk refleksjon i et trygt miljø og selvtillit. Positive rollemodeller, som for eksempel praksisveilederen, kan være en god støtte for studentene. Gjennom å demonstrere egen kompetanse i praksis kan veilederen hjelpe studentene til å se hva som er viktig for å bli en profesjonell sykepleier.

\section{¿Positive rollemodeller, som for eksempel praksisveilederen, kan være en god støtte for studentene.»}

Tilhørighet ble viktig når studentene ble inkludert og akseptert i praksis som en del av et team. Støtte fra medstudenter og refleksjon over praksis var viktig for å utvikle en god forståelse for blant annet teamarbeid (므).

På bakgrunn av dette har lærere ved Norges teknisk-naturvitenskapelige universitet (NTNU), Institutt for samfunnsmedisin og sykepleie (ISM), gjennom et prosjekt satt søkelyset på utvikling av sykepleieridentitet gjennom et såkalt praksisseminar. Her deltok studentene med sine erfaringer fra praksis sammen med lærere fra utdanningen.

\section{Metode}

Deltakerne på seminaret var bachelorstudenter i sykepleie ved NTNU/ISM som gjennomførte kliniske praksisstudier innen medisinsk fagområde i andre studieår ved St. Olavs Hospital i Trondheim. I tillegg deltok alle lærere som hadde veiledningsansvar på de ulike avdelingene. 
Skriftlig og muntlig informasjon ble gitt studentene ved praksisstart, blant annet om hensikten med seminaret og krav til forberedelse. Et informasjonsskriv om seminaret ble også gitt til studentenes praksisveiledere, som for øvrig var invitert til seminaret. Seminaret ble lagt til slutten av praksisperioden og hadde obligatorisk deltakelse.

Som forberedelse til seminaret ble studentene bedt om å utarbeide en tjue minutters presentasjon av sine avdelinger, etterfulgt av ti minutter til spørsmål og diskusjon.

Studentene fikk i oppdrag å presentere følgende:

- Pasienter (de vanligste diagnosene og kort om behandling)

- Sykepleiernes oppgaver og ansvar i avdelingen

- Sykepleierens kompetanse: Hvilke ferdigheter og kunnskaper kreves av sykepleiere som jobber der?

- Sykepleiere har både en selvstendig og assisterende funksjon - eksempler på det fra din/deres avdeling?

\section{Gjennomføring}

Et pilotseminar for 25 studenter fordelt på 8 medisinske avdelinger ble gjennomført våren 2015. Her ble selve gjennomføringen av seminaret testet og studentenes evalueringer lagt til grunn for justeringer. I hovedprosjektet ble antallet avdelinger oppjustert og antallet presentasjoner redusert ved at studenter som hadde praksis innen samme fagområde (for eksempel hjerte/kar), men på ulike sengeposter, utarbeidet en felles presentasjon.

Hovedprosjektet omfattet studenter fra tre praksisseminarer som ble gjennomført fra høsten 2015 til og med høsten 2016. Selve seminaret varte i seks timer og omfattet studenter fra fjorten ulike medisinske avdelinger. Disse ble fordelt på to dager med tilnærmet likt antall avdelinger og presentasjoner.

\section{Evaluering}

Et evalueringsskjema ble utarbeidet for å undersøke studentenes faglige utbytte av seminaret. Det ble blant annet spurt om i hvilken grad seminaret bidro til å klargjøre sykepleiernes kompetanse, oppgaver og ansvar i avdelingen, samt deres selvstendige og assisterende funksjon. I tillegg ble de spurt om samarbeidet med andre studenter hadde vært faglig og personlig utviklende.

Med dikotome svaralternativer ble de også spurt om hvorvidt praksisseminarer kan være alternativer til ordinær lærerveiledning i praksis, og om flere praksisseminarer burde vært arrangert ved utdanningen. Endelig ble studentene bedt om å komme med forslag til eventuelle endringer eller forbedringer av seminaret.

Studentene svarte anonymt på evalueringsskjemaet på slutten av seminardagen. Deskriptive analyser ble utført ved hjelp av statistikkprogrammet SPSS.

\section{Resultater}

I alt 124 studenter deltok i prosjektet, hvorav 90 prosent var kvinner og 10 prosent menn. Gjennomsnittsalderen var 24 år. 
Når det gjaldt i hvilken grad praksisseminaret ga faglig utbytte, svarte 93 studenter (75 prosent) i stor eller svært stor grad, mens 2 (1,6 prosent) opplevde liten grad av faglig utbytte.

Figur 1: Faglig utbytte av seminaret $(n=124)$

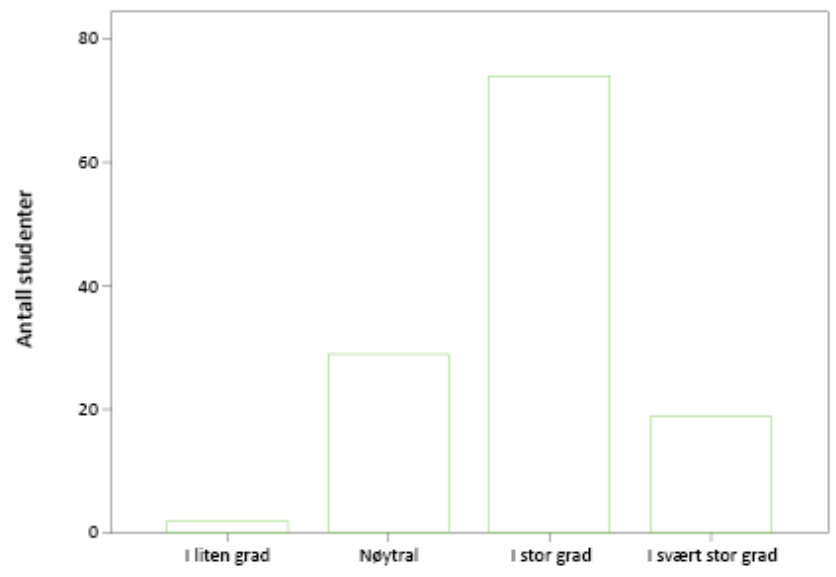

På spørsmål om det å samarbeide med andre studenter i forkant av seminaret hadde vært faglig og personlig utviklende, svarte 76 (61,3 prosent) av respondentene at de var enige eller helt enige, mens 12 (9,7 prosent) var uenige eller sterkt uenige.

Figur 2: Samarbeid med medstudenter for faglig og personlig utvikling $(n=124)$

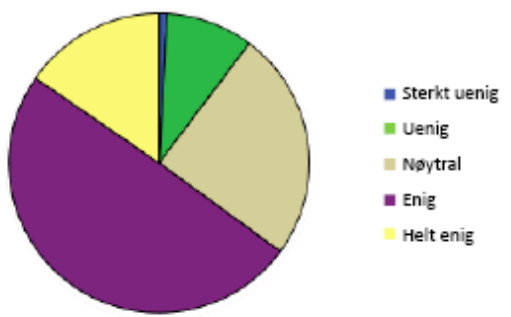

På spørsmål om det å forberede og gjennomføre en presentasjon foran medstudenter og lærere hadde vært faglig og personlig utviklende, svarte 83 (66,9 prosent) at de var enige eller helt enige, mens 13 (10,5 prosent) var uenige eller sterkt uenige. 


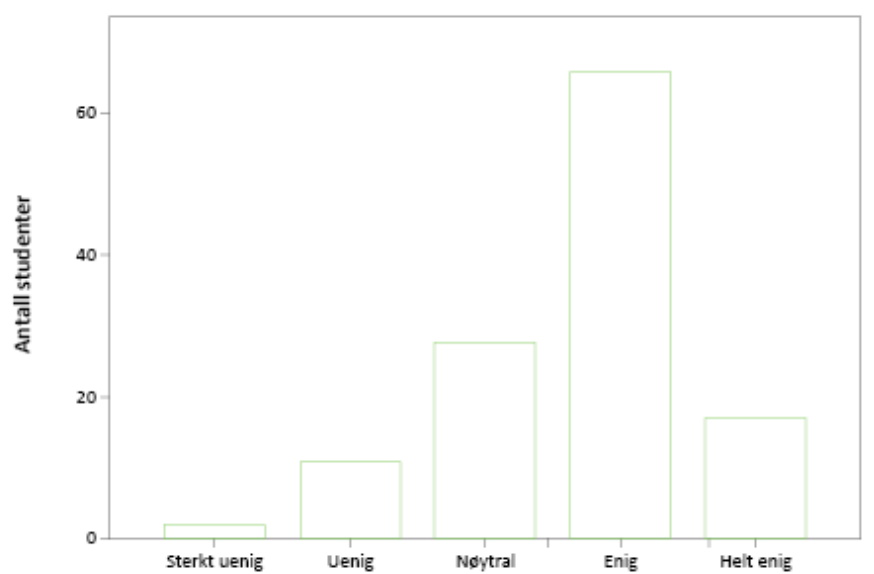

Når det gjaldt i hvilken grad praksisseminaret bidro til å klargjøre sykepleierens kompetanse og selvstendige og assisterende funksjon, svarte 83 (67 prosent) av respondentene at seminaret i stor eller svært stor grad bidro til det, mens 7 (5,6 prosent) svarte i liten eller svært liten grad.

Figur 4: Klargjøring av sykepleierens kompetanse og selvstendige og assisterende funksjon $(n=123)$

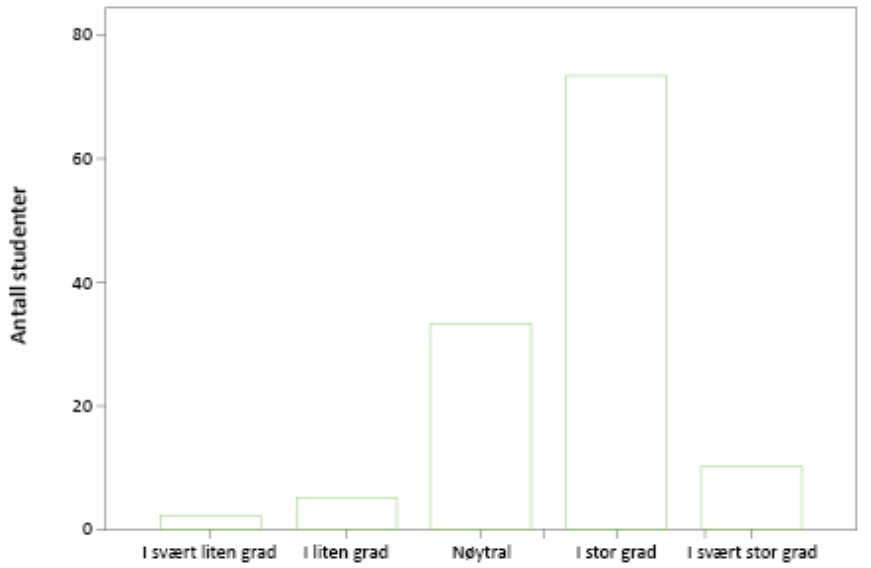

På spørsmål om i hvilken grad praksisseminaret bidro til å klargjøre sykepleierens oppgaver og ansvar i medisinsk avdeling, svarte 93 (75 prosent) i stor eller svært stor grad, mens 4 (3,2 prosent) mente at det i liten eller svært liten grad bidro til dette. 


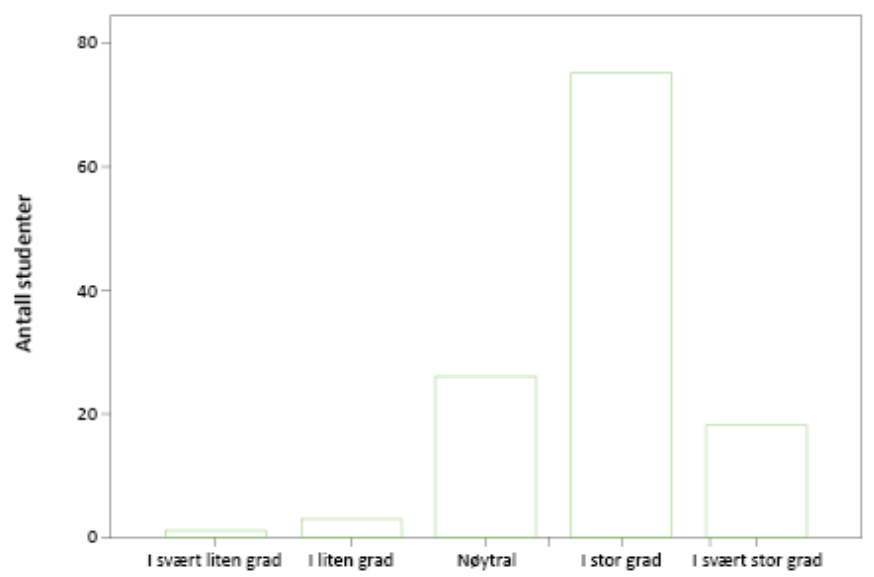

På spørsmål om hvorvidt det burde arrangeres flere praksisseminarer ved utdanningen, svarte 86 (69,4 prosent) av studentene ja, mens 29 (23,4 prosent) var usikre og 9 (7,3 prosent) svarte nei. På spørsmål om praksisseminar kunne være et alternativ til ordinær veiledning i praksis, svarte 74 (59,5 prosent) ja, mens 35 (28,2 prosent) var usikre og 15 (12,1 prosent) svarte nei.

\section{Diskusjon}

Hensikten med praksisseminaret var å samle studenter og lærere til en diskusjon rundt sykepleierens kompetanse, funksjon, oppgaver og ansvar i medisinsk avdeling.

Majoriteten av studentene (67 prosent) mente at seminaret bidro til en klargjøring av sykepleierens kompetanse og selvstendige og assisterende funksjon. Enda flere (75 prosent) mente at seminaret bidro til å klargjøre sykepleierens oppgaver og ansvar i medisinsk avdeling, noe som kan bidra til å utvikle sykepleieridentitet.

Resultatene tyder på at et seminar kan være en egnet arena for å utvikle sykepleieridentitet, siden denne undervisningsformen krever en mer aktiv studentrolle gjennom fremlegg, diskusjon og dialog med medstudenter og lærere (3).

\section{Samarbeid}

Studenter fra samme avdeling fikk dessuten øvelse i å samarbeide om fremlegget. Gjennom samarbeid, dialog og diskusjoner kan studentene få en annen og mer nyansert forståelse av sykepleiefaget enn gjennom for eksempel selvstudium. Nettopp ved å diskutere sykepleierens utøvende funksjon i avdelingen kan studentene bli mer oppmerksomme på hva sykepleie er, noe som igjen kan øke deres forståelse av sykepleiefaget.

Dette er også i tråd med Walker og medarbeidere (6), som viser at støtte fra andre studenter er en viktig faktor for å utvikle sykepleieridentitet, sammen med muligheten til å få reflektere over fagutøvelsen. 
En høy andel av studentene (61,3 prosent) mente at å samarbeide med andre studenter i forkant av seminaret var faglig og personlig utviklende. Likeså sa over halvparten (66,9 prosent) det samme om det å forberede og gjennomføre en presentasjon for medstudenter og lærere. Studentenes forberedelser til seminaret kan ha vært med på å bevisstgjøre dem om sykepleierens funksjonsområder samt gi dem kunnskap om pasientgruppen i avdelingen.

\section{«Støtte fra andre studenter er en viktig faktor for å utvikle sykepleieridentitet.»}

Videre kan resultatene tyde på at samarbeid mellom studenter og lærere og det å møte medstudenter i samme situasjon kan ha bidratt til å klargjøre og bygge sykepleieridentitet. I diskusjoner etter egne fremlegg fikk studentene innblikk i medstudenters og læreres ulike synspunkter og trening i å forsvare eller utdype egne vurderinger og argumenter.

Dette støttes av Walker og medarbeidere (므), som understreker viktigheten av å møtes i grupper for å dele kunnskap, noe som gir studentene mulighet til å reflektere over egen praksis. Walker og medarbeidere (므) sier dessuten at støtte fra og samarbeid med andre studenter gir en bedre forståelse for teamarbeid som en del av sykepleierens funksjon. Videre fremhever de at sykepleierstudenter må få muligheter til å stille spørsmål, noe som gjøres best i en kjent gruppe i et trygt miljø.

\section{Tilbakemelding}

Gjennom sin utdanning frem mot autorisasjon som sykepleier møter studentene ulike rollemodeller, deriblant praksisveiledere og lærere. Ifølge Walker og medarbeidere (6) er gode rollemodeller en viktig faktor for utvikling av sykepleieridentitet. På seminaret fikk studentene respons fra lærere med ulik klinisk erfaring og fagkompetanse, og fikk således belyst flere sider av sykepleierfaget.

Dette er også i tråd med Walker og medarbeidere (6), som fant at lærere gjennom vektlegging av kritisk tenkning og konstruktiv tilbakemelding kan bidra til gradvis utvikling av sykepleieridentitet hos studentene.

\section{Praksisstedets innstilling}

På spørsmål om i hvilken grad praksisstedet hadde vært positivt innstilt til seminaret, svarte 57 studenter (45,9 prosent) i stor eller svært stor grad (data ikke vist). Veilederne i praksis var invitert med på seminaret, men møtte dessverre ikke opp. Grunnen er uklar, men kan ha sammenheng med tidskonflikt og at det ikke hadde blitt kommunisert tydelig nok til praksisveilederne hvor viktig det var at de deltok på seminaret.

Ifølge Matthew-Maich og medarbeidere (7) er det viktig at student, praksisveileder og lærer deler kunnskaper og erfaringer med hverandre. Ettersom praksisveilederne ikke var til stede på seminaret, gikk studentene glipp av verdifulle tilbakemeldinger fra og diskusjon med dem. Dette understøttes av Walker og medarbeidere (6), som fant at praksisveilederne er nøkkelpersoner for utvikling av sykepleieridentitet hos studenter.

\section{Variasjon}


Majoriteten av studentene (75 prosent) hadde et faglig utbytte av seminaret. Flertallet (69,4 prosent) mente at det burde arrangeres flere slike seminarer ved utdanningen. Over halvparten (59,5 prosent) mente dessuten at et praksisseminar kunne være et alternativ til ordinær veiledning i praksis. Resultatene kan tyde på at studentene ønsker variasjon i hvordan veiledning i praksis gjennomføres. I åpne spørsmål i evalueringsskjemaet fremhevet studentene på eget initiativ at faglige diskusjoner var lærerike.

\section{¿ «Flertallet mente at det burde arrangeres flere slike seminarer ved utdanningen.»}

For utdanningen kan det bety at en må se på mulighetene til å implementere praksisseminar som en av flere undervisnings- og veiledningsmetoder ved kliniske praksisstudier gjennom hele studiet. Temaer for slike praksisseminarer kan selvsagt variere, fra ulike pasientcase og etiske dilemmaer til konkrete problemstillinger fra praksis, i tråd med hva studentene selv foreslo i evalueringsskjemaet.

\section{Studentaktiv læring}

En styrke ved dette prosjektet er at vi som lærere har fått kunnskap om hva som er viktig for studentenes læring. Seminarformen er en studentaktiv læringsmetode, der studentene gjennom egen deltakelse og aktivitet kan øke sin personlige og faglige sykepleierkompetanse.

Studentene fikk utlevert et evalueringsskjema på slutten av dagen, som hadde 100 prosent oppslutning. Som lærere har vi god tilgang på respondenter, da ulike prosjekt kan inngå som en del av undervisningen.

En svakhet ved prosjektet er at deler av evalueringsverktøyet tar opp flere temaer i et og samme spørsmål. Vi får derfor ikke videre innsikt i den enkelte komponent i spørsmålet, noe som kan være årsaken til at mange svarte nøytralt på noen spørsmål, jamfør figur 4. Et spørreskjema gir oss ikke mulighet til å gå i dybden eller følge opp utsagn som vi ser kunne vært utdypet. Fokusgruppeintervjuer i tillegg til evalueringsskjema kunne ha avdekket hva studentene la i de ulike komponentene.

\section{Oppsummering}

Diskusjon og klargjøring av sykepleierens kompetanse, funksjon, oppgaver og ansvar kan bidra til å styrke sykepleieridentiteten blant bachelorstudenter i sykepleie. Et praksisseminar kan være en egnet arena for dette, da det fremmer samarbeid og diskusjoner mellom medstudenter og lærere og bidrar til faglig og personlig utvikling hos studentene. Derfor må sykepleierutdanninger i fremtiden se på mulighetene til å implementere praksisseminar som en veiledningsmetode ved kliniske praksisstudier gjennom hele studiet for å øke studentenes bevisstgjøring av fag og profesjon.

\section{Referanser}

1. Forskrift 25. januar $2008 \mathrm{nr} .128$ til rammeplan for sykepleierutdanning. Tilgjengelig fra: https://lovdata.no/dokument/SF/forskrift/2008-01-25-128 (nedlastet 10.01.2018). 
2. Kunnskapsdepartementet. Rammeplan for sykepleierutdanningen. Oslo;

2008. Tilgjengelig fra:

https://www.regjeringen.no/globalassets/upload/kd/vedlegg/uh/rammeplaner/helse/rammeplan_sykepleierutdanning_08.pdf (nedlastet 08.01.2018).

3. Pettersen RC. Kvalitetslæring i høgere utdanning: innføring i problemog praksisbasert didaktikk. Oslo: Universitetsforlaget; 2005.

4. Jaques D. Team based learning / learning in groups: a handbook for improving group work. 3. utg. London: Kogan Page; 2002.

5. Adams K, Hean S, Sturgis P, Clark JM. Investigating the factors influencing professional identity and first-year health and social care students. Learning in Health and social care. 2006;5(2):55-68.

6. Walker S, Dwyer T, Broadbent M, Moxham L, Sander T, Edwards K. Constructing a nurse identity within the clinical environment: the student nurse experience. Contemp Nurse. 2014;49:103-12.

7. Matthew-Maich N, Martin L, Ackerman-Rainville R, Hammond C, Palma A, Sheremet D, et al. Student perceptions of effective nurse educators in clinical practice. Nurs Standard. 2015;29(34):45-58. 